\title{
Assessment of fibrosis and vascularization of bone marrow stroma of Chronic Myeloid Leukemia patients treated with imatinib mesylate and their relationship with the cytogenetic response
}

\author{
Caroline Regina de Jesus ${ }^{1}$, Lee I-Ching ${ }^{1}$, Teresinha de Jesus Carvalho Neiva ${ }^{2}$, \\ Cidônia de Lourdes Vituri²,*
}

\author{
${ }^{1}$ Laboratory of Pathology, Oncology Research Center (CEPON), Florianópolis, Brazil, ${ }^{2}$ Center for Health Sciences, \\ Department of Clinical Analyses, Universidade Federal de Santa Catarina
}

\begin{abstract}
Chronic Myeloid Leukemia (CML) is a myeloproliferative disease characterized by the presence of the Philadelphia chromosome (translocation between chromosomes 9 and 22), resulting in the formation of the hybrid BCR-ABL protein. Currently, the treatment of CML patients is performed with imatinib mesylate (IM), which promotes the elimination of leukemic cells by inhibiting the kinase activity of BCR-ABL. This study evaluated the effectiveness of IM by monitoring 22 CML patients in a chronic phase treated at the CEPON/SC with IM for a minimum follow-up period of two years. Cytogenetic Response (CR) and bone marrow biopsies $(\mathrm{BMB})$ were evaluated before and after IM treatment. BMB were evaluated by detection of reticulin degree and vascularization. The results were correlated to the CR. Mean time to achieve CR was 9 months and was attained by $77.27 \%$ of the patients. The results from the initial BMB analysis showed that $59.09 \%$ presented reticulin of between $2+$ and $4+$ whereas after treatment, only $27.17 \%$ presented this degree. With regard to vascularization of the initial sample, 90.91\% were graded between II and IV, whereas after treatment, 40.91\% had this degree. The results suggest a positive correlation of degree of reticulin and vascularization with $\mathrm{CR}$.
\end{abstract}

Uniterms: Chronic myeloid leukemia/treatment. Imatinib mesylate/effectiveness/leukemia treatment. Bone marrow/biopsies. Fibrosis. Vascularization.

\begin{abstract}
A Leucemia Mielóide Crônica (LMC) é uma doença mieloproliferativa caracterizada pela presença do cromossomo Filadélfia (translocação entre os cromossomos 9 e 22), que resulta na formação da proteína híbrida BCR-ABL. Atualmente o tratamento de pacientes com LMC é realizado com mesilato de imatinibe (MI), o qual promove a eliminação das células leucêmicas pela inibição da atividade quinase de BCR-ABL. O presente estudo avaliou a eficácia do MI por meio do acompanhamento de pacientes portadores de LMC em fase crônica, atendidos no CEPON/SC tratados com MI pelo tempo mínimo de dois anos. Foram avaliadas a Resposta Citogenética (RC) e as biópsias de medula óssea (BMO) antes e após o tratamento com MI. As BMO foram avaliadas quanto ao grau de reticulina e vascularização. Os resultados correlacionaram-se com a RC cujo tempo médio para obtenção da RC foi de 9 meses, sendo atingida por $77.27 \%$ dos pacientes. Na primeira BMO, $59.09 \%$ dos pacientes apresentaram grau de reticulina entre $2+$ e $4+$ e após o tratamento, apenas $27.17 \%$ apresentaram esta graduação. Quanto à vascularização da primeira amostra, 90.91\% foram graduadas entre II e IV e após o tratamento, 40.91\% apresentaram esta graduação. Os resultados sugerem uma correlação diretamente proporcional entre os graus de reticulina e vascularização com a RC.
\end{abstract}

Unitermos: Leucemia mielóide crônica/tratamento. Mesilato de imatinibe/eficácia/tratamento da leucemia. Medula óssea/biópsia. Fibrose. Vascularização.

*Correspondence: C. L. Vituri. Departamento de Análises Clínicas, Centro de Ciências da Saúde - CCS, Universidade Federal de Santa Catarina, 88010970 - Florianópolis - SC, Brasil. E-mail: cids@ccs.ufsc.br 


\section{INTRODUCTION}

Chronic Myeloid Leukemia (CML) is a clonal disease characterized by the presence of the Philadelphia $\left(\mathrm{Ph}^{1}\right)$ chromosome, which results from a reciprocal and balanced translocation between chromosomes 9 and 22 (Sawyers, 1999). The molecular consequence of this translocation is the generation of a hybrid protein called BCR-ABL, which presents increased tyrosine kinase activity, compromising the regulation of the cell cycle (Faderl et al., 1999; Sattler, Griffin, 2003). The diagnostic presumptive of CML usually arises with the results obtained in blood cell counts. The total leukocyte count is elevated and is invariably greater than $25,000 / \mu \mathrm{L}$. The total leukocyte count rises progressively in untreated patients. Granulocytes at all stages of development are present in the blood and are generally morphologically normal. Blast cell prevalence is approximately $3 \%$ but can range from $0 \%$ to $10 \%$. The platelet count is elevated in approximately $50 \%$ of patients and largely normal in the rest. Definitive diagnosis is obtained by evaluation of bone marrow biopsy (BMB), myelogram and cytogenetic examination (Lichtman et al., 2006; Brasil, Ministério da Saúde, 2001; Geary, 2000).

The hematopoietic microenvironment of bone marrow $(\mathrm{BM})$ is also changed in CML. This microenvironment is composed of stromal cells, accessory cells and their products (extracellular matrix proteins and cytokines), which influence the self-renewal, proliferation and differentiation of hematopoietic stem and progenitor cells (Vituri et al., 2000; Vituri et al., 2006). Collagen type III, visualized by silver staining, is generally increased at diagnosis (reticulin fibrosis). In almost half of patients, the reticulin is remarkably increased in BM, and this increase shows a correlation with the proportion of megakaryocytes (Lichtman et al., 2006; Guimarães et al., 2006). The BM of CML patients have a two-fold increase in microvessel density compared to healthy controls while in CML there is more angiogenesis in BM than is found in other forms of leukemia. The concentration of vessels, or the BM microvessel density (MVD), can easily be investigated by immunohistochemistry in hematological disorders because the BM is a primary site of disease activity and readily accessible tissue. This measurement is also useful for evaluating the prognosis of patients (Panteli et al., 2004).

Regarding treatment of CML, imatinib mesylate (IM) is currently the first-line drug of choice. This drug, chemically known as 2-phenylaminopyrimidine, entered clinical trials in 1998 as STI571. The drug is a potent and specific inhibitor of all ABL related kinases, Platelet Derived Growth Factor (PDGF) and c-kit. As the hybrid protein $\mathrm{BCR}-\mathrm{ABL}$ is responsible for the occurrence of events related to the LMC, its inhibition leads to the elimination of leukemic cells (Savage, Antman, 2002).

This study examined the BM stromal of CML patients treated with IM correlating to other laboratory parameters. The effectiveness of the drug was analyzed over a two-year period of monitoring based on observation of the time needed for patients to achieve CR. The $\mathrm{BMB}$ were evaluated for degree of reticulin (fibrosis) and degree of vascularization. Finally, the results obtained from the analysis of BMB collected after treatment, were correlated to CR.

\section{PATIENTS AND METHODS}

Firstly, a survey was carried out involving all registered patients with CML treated using IM at the Oncology Research Center Units of Santa Catarina, in Florianópolis, Santa Catarina (CEPON/SC) in the period spanning from August 2005 to August 2007. During the period, 67 patients were enrolled, all from Santa Catarina. Only the 22 patients that presented at least two reports of anatomical and pathological bone marrow, one of diagnosis and another after $6 \pm 2$ months of treatment with IM, were considered for the study. Therapy with IM, at a daily dosage of $400 \mathrm{mg}$ was given throughout the study, and no other cytotoxic or supportive agents were combined to IM.

\section{Inclusion criteria}

Patients with CML at a chronic phase, $\mathrm{Ph}^{1}$ chromosome positive, treated with IM, submitted to two BMB, and able to perform histological sections, were included. The determination of the stage of disease was done according to the laboratory peripheral blood findings (Table I) and findings on BMB (Table 2) (Sawyers, 1999). All patients included were previously treated with IFN-a before starting the use of IM. Patients were informed in accordance with the guidelines of the local ethics committee (CONEP/ ANVS). The demographics and baseline characteristics of the patients included in the study are shown in Table III.

TABLE I - Laboratory findings of peripheral blood of CML patients, at a chronic phase

\begin{tabular}{l}
\hline Peripheral Blood \\
\hline Leukocytosis $\left(>25,000 / \mathrm{mm}^{3}\right)$ \\
Platelets: Increased or normal \\
Basophilia \\
Reduced activity of leukocyte alkaline phosphatase \\
All stages of granulocyte differentiation visible in peripheral \\
blood smears
\end{tabular}


TABLE II - Findings on BMB of CML patients, at a chronic phase

\begin{tabular}{l}
\hline Bone Marrow \\
\hline Hypercellularity \\
Reduction of intramedullary fat \\
Increased number of megakaryocytes \\
Less than $10 \%$ of blasts and promyelocytes \\
Increased myeloid to erythroid cell ratio \\
\hline
\end{tabular}

\section{Cytogenetic response}

The analysis of Cytogenetic Response (CR) was done by examining the medical records of patients. CR was acknowledged when patients achieved Major Cytogenetic Response, according to current treatment guidelines for CML in Brazil (Table IV). The tests were evaluated individually and were used to analyze a possible correlation between CR and degrees of reticulin and vascularization. The data used to construct the graph considered the percentage of chromosome $\mathrm{Ph}^{1}$ positive cells and the grading of the second $\mathrm{BMB}$, related to the degree of reticulin and vascularization (Figures 6 and 7).

\section{Gomori staining}

BMB slides were prepared from paraffin-embedded blocks. After deparaffinization, the BMB slides were immersed in potassium permanganate solution $0.5 \%$ (Quimex) for 2 minutes. The slides were then washed and immersed quickly in oxalic acid solution 5\% (Vetec). Subsequently, these were immersed in alumen iron solution 5\% (Reagen) for 2 minutes. After washing, the slides were immersed in silver ammonium solution Gomori (Vetec) for 2 minutes. After immersion in distilled water, the slides were quickly immersed in formalin

TABLE III - Patient demographics and baseline characteristics

\begin{tabular}{lc}
\hline Patient demographics and baseline characteristics & Values \\
\hline $\mathbf{N}^{\mathbf{0}}$ patients & 22 \\
$\quad$ Male Sex, \% & 50 \\
$\quad$ Median Age (range) & $42.36(18$ to $69 \mathrm{y})$ \\
History of illness, usage of INF- $\alpha$, number of patients (\%) & $12(54.54)$ \\
$\quad$ Hematologic/cytogenetic resistance & $7(31.82)$ \\
$\quad$ Intolerance & $3(13.64)$ \\
$\quad$ No reason & \\
INF- $\alpha$ therapy duration, number of patients (\%) & $15(68.18)$ \\
$\quad>1$ year & $7(31.82)$ \\
$\quad<1$ year & $10(45.46)$ \\
Splenomegaly, number of patients (\%) & \\
Time diagnosed with disease (early treatment with imatinib), number of patients (\%) & $0(0)$ \\
$\quad<1$ year & $22(100)$ \\
$\quad>1$ year & \\
Hemoglobin level at diagnosis, number of patients (\%) & $14(63.64)$ \\
$\quad<12.0 \mathrm{~g} / \mathrm{dl}$ & $8(36.36)$ \\
$\quad>12.0 \mathrm{~g} / \mathrm{dl}$ & \\
Leukocytes count at diagnosis, number of patients (\%) & $0(0)$ \\
$\quad<10,000 / \mathrm{mm}^{3}$ & $15(68.18)$ \\
$\quad 10,000-50,000 /$ mm $^{3}$ & $7(31.82)$ \\
$\quad>50,000 / \mathrm{mm}^{3}$ & \\
Platelet count at diagnosis, number of patients (\%) & $13(59.09)$ \\
$\quad<450,000 / \mathrm{mm}^{3}$ & $9(40.91)$ \\
$\quad>450,000 / \mathrm{mm}^{3}$ & $14(63.64)$ \\
\hline Peripheral blasts at $\mathbf{1}^{\text {st }}$ evaluation, number of patients (\%) & \\
\hline
\end{tabular}


TABLE IV - Criteria for classification of CR (Brasil. Ministério da Saúde, 2001)

\begin{tabular}{l}
\hline Cytogenetic Response \\
\hline Major Cytogenetic Response: \\
- Complete Cytogenetic Response: $0 \% \mathrm{Ph}^{1}$ positive cells \\
- Partial Cytogenetic Response: $1 \%$ to $<35 \% \mathrm{Ph}^{1}$ positive cells \\
Minor Cytogenetic Response: $35 \%$ to $90 \% \mathrm{Ph}^{1}$ positive cells \\
Lack of Cytogenetic Response: $>90 \% \mathrm{Ph}^{1}$ positive cells
\end{tabular}

solution 10\% (Vetec) and washed under running water. Subsequently, the slides were immersed in chloride old solution 1\% (Synth) and in sodium thiosulfate solution $5 \%$ (Vetec). Finally, the sections were coverslipped with a specific fixation fluid (Entellan, Merck) (Michalany J, 1980).

\section{- Measurement of fibrosis degree (reticulin fiber network)}

The histological sections of BMB were examined using a light microscope. The entire section was scanned at $100 \mathrm{x}$ magnification. Positive and negative control samples were evaluated concomitantly. The positive controls were from patients with Primary Myelofibrosis (Chronic Idiopathic Myelofibrosis) and the negative controls were from patients without hematological disease. The reticulin fibers were graded as 0 to $4+$. The classification used was based on the Bauermeister Graduation (Alves, 2009). The normal samples had a degree of reticulin 0 , indicating absence of reticulin, and served as negative controls (Figure 1A). Samples with the presence of thin and scattered fibers

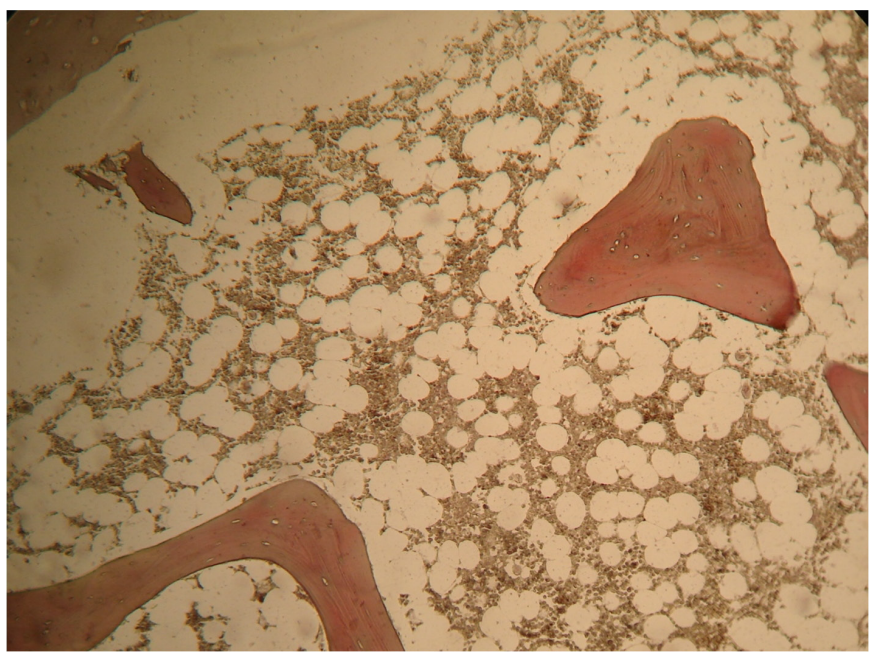

FIGURE 1A - Histological sections of normal BMB (degree 0 ) stained by Gomori silver solution, $100 \mathrm{x}$ magnification. The fibers are stained in gray.

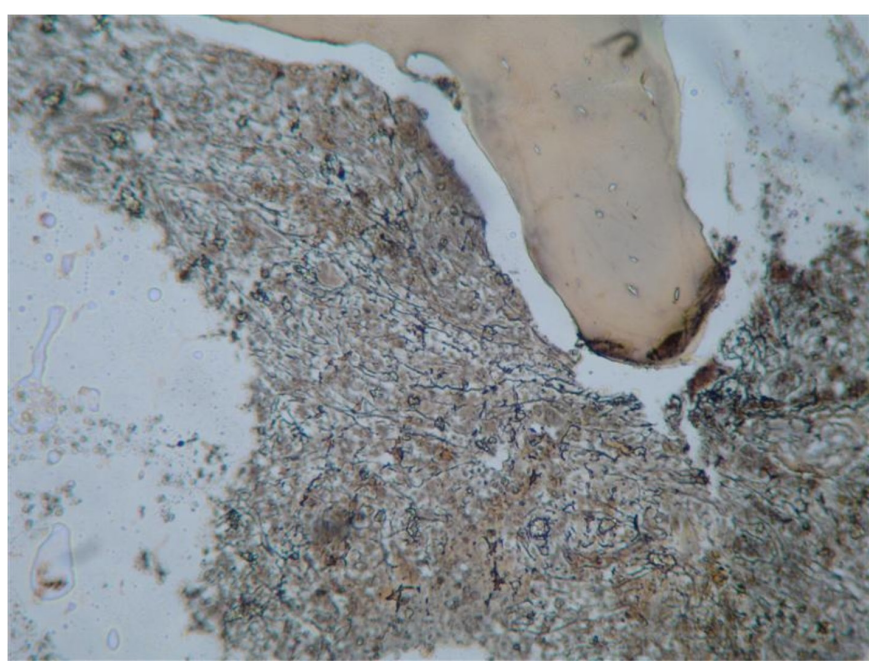

FIGURE 1B - Histological section of BMB stained by Gomori silver solution, $100 \mathrm{x}$ magnification. The fibers are stained in gray. This sample presents reticulin network graded as +4 .

or a focal network had degree $1+$, also normal. The visualization of a thin fiber network in most of the fragment, and absence of thick fibers, represent degree $2+$. Samples with a diffuse network of thin fibers with scattered thick fibers and absence of collagen were graded $3+$. Samples with a diffuse network of coarse fibers and bundles of collagen were graded as 4+, similar to the positive controls (Figure 1B) (Alves, 2009; Bueso-Ramos et al., 2004).

\section{Immunohistochemistry for CD34}

Bone marrow microvessels were visualized by an immunohistochemical labelled for CD34. Although the CD34 antibody also stained myeloid progenitors, the number of cells stained was sufficiently small as not to interfere with our analysis. Nevertheless, vessel specificity the CD34-stained stroma considered for analysis was documented thoroughly. In general, CD34 has been found to be a useful antigen for assessing intratumor angiogenesis (Kvasnicka et al, 2004).

Slides of the BMB were prepared from paraffin-embedded blocks. After deparaffinization, slides were steam pretreated in a solution containing $200 \mathrm{~mL}$ of methanol and $4 \mathrm{~mL}$ of hydrogen peroxide (Merck, concentration $30 \%$ ) for 20 minutes, protected from the light. After washing with buffer at $\mathrm{pH} 7.2$, the slides were immersed in a citrate buffer, with pH 6.0 called Target Retrieval (Dako), for exposure to the antigen, for 45 minutes in a water bath at $85{ }^{\circ} \mathrm{C}$. After cooling the solution for approximately 20 minutes, the slides were washed in buffer solution. Before incubating the slides, the tissue sections were demarcated with a hydrophobic pen. The primary antibody (CD34, 
Novocastra) was then incubated overnight in a 1:100 dilution at room temperature. The biotin-streptavidin kit (Novocastra) was used for antigen visualization and was incubated for 30 minutes at room temperature. Finally, Diaminobenzidine (DAB, Dako) was used as the substrate for the abovementioned marker enzyme. The sections were counterstained with hematoxylin (Merk) and coverslips were applied with a specific fixation fluid (Entellan, Merk) (Dabbs, 2006).

\section{- Measurement of microvessel density}

The BMB histological sections, stained immunohistochemically for CD34, were examined using a light microscope in order to identify the areas with intense vascularization. The entire section was scanned at $100 \mathrm{x}$ magnification. Three areas, with the highest number of microvessels, were chosen and defined as the hot spots. Microvessels were then counted at $400 \mathrm{x}$ magnification in each of these hot spots.

The final MVD number was assigned by taking the average of the three separate visual counts. Microvessels were identified as endothelial cells, either single or clustered in nets or tubes, clearly separated from one another, either with or without a lumen (Figure 2A). Vessels with muscular walls and vessels in the periosteum and open sinusoids were excluded. Measurement also excluded areas occupied by fat. The vascularization was graded from I to IV degrees (Kvasnicka, 2004). Positive and negative control samples were evaluated concomitantly. The positive controls were obtained from patients with Multiple Myeloma whereas the negative controls were from patients without hematological disease (Figure 2B).

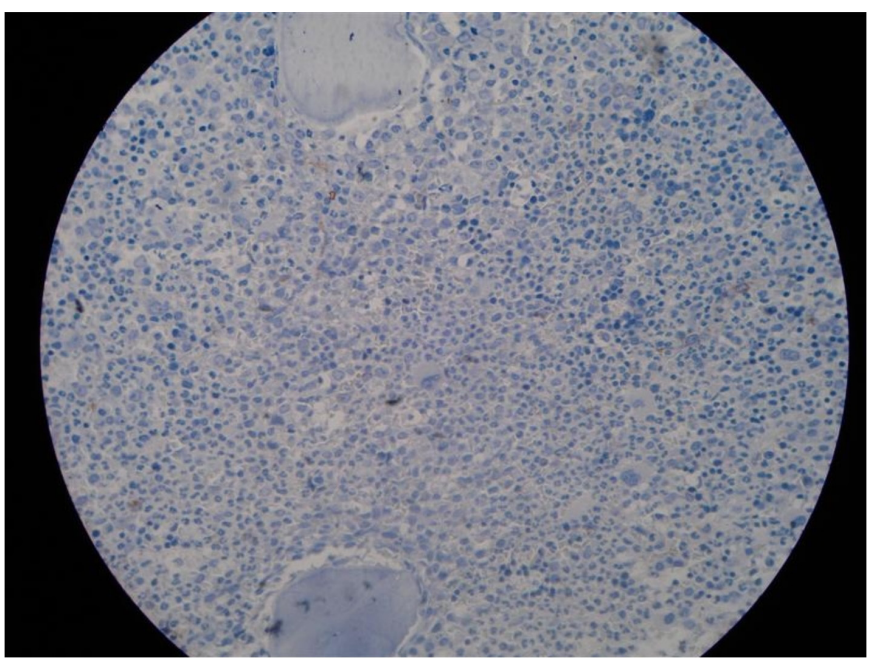

FIGURE 2A - Histological section of normal (degree I) BMB stained immunohistochemically for CD34, $100 \mathrm{x}$ magnification.

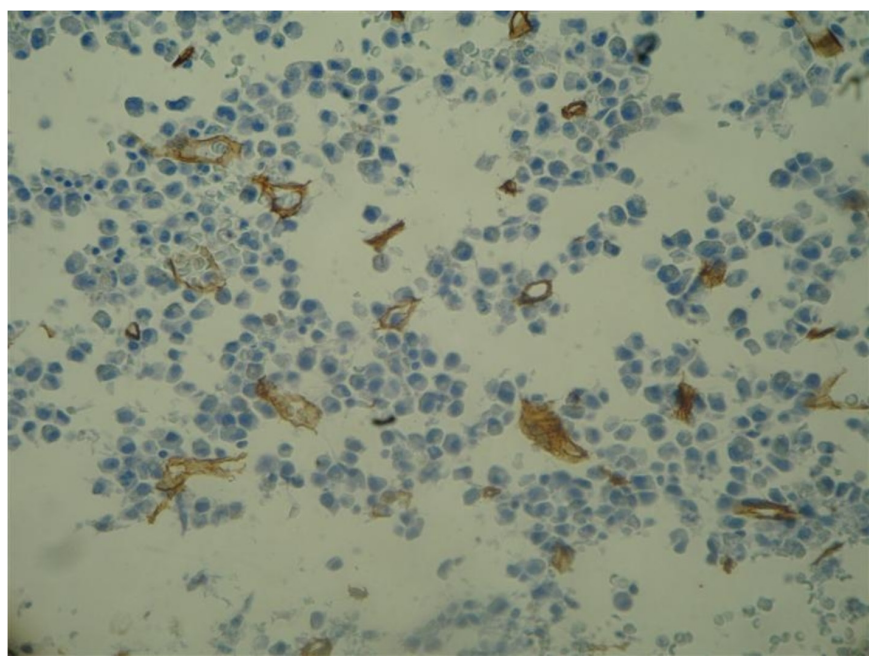

FIGURE 2B - Histological section of BMB stained immunohistochemically for CD34, $400 \mathrm{x}$ magnification. Microvessels are stained in brown, clearly separated from one another, and either with or without a lumen. This sample was graded as degree IV vascularization.

\section{Data and statistical analysis}

The percentage of patients that achieved CR in the two years of treatment and the degree of reticulin and vascularization of the BMB were evaluated. The first biopsy was performed before IM treatment and the second sample was collected after at least six months of IM treatment.

The tests of correlation were also performed between CR and the degree of vascularization and reticulin from the second BMB. The patients who responded were those with less than $35 \%$ of $\mathrm{Ph}^{1}$ chromosome positive cells on the cytogenetic examinations. The evaluation of this correlation was verified with the non-parametric test of Spearman, considering $\mathrm{p}<0.05$ as the minimum level of significance. Results were expressed in absolute values of correlation (r), where " 0 " indicates total absence of linear correlation and " 1 " a perfect linear relationship. Statistical analysis was performed using the INSTAT-2 program.

\section{RESULTS}

1- The study was conducted in 22 individuals treated with IM that met the inclusion criteria. During the two years of monitoring, $77.27 \%$ patients achieved CR (Figure 3 ). By the sixth month, nearly $22 \%$ of patients had achieved CR and at the tenth month, 50\% had attained this response. The last patient attained CR just in the fourteenth month. Beyond this timepoint, no other patients achieved $\mathrm{CR}$ throughout the rest of the monitoring. The average time taken to attain CR was 10 months. 


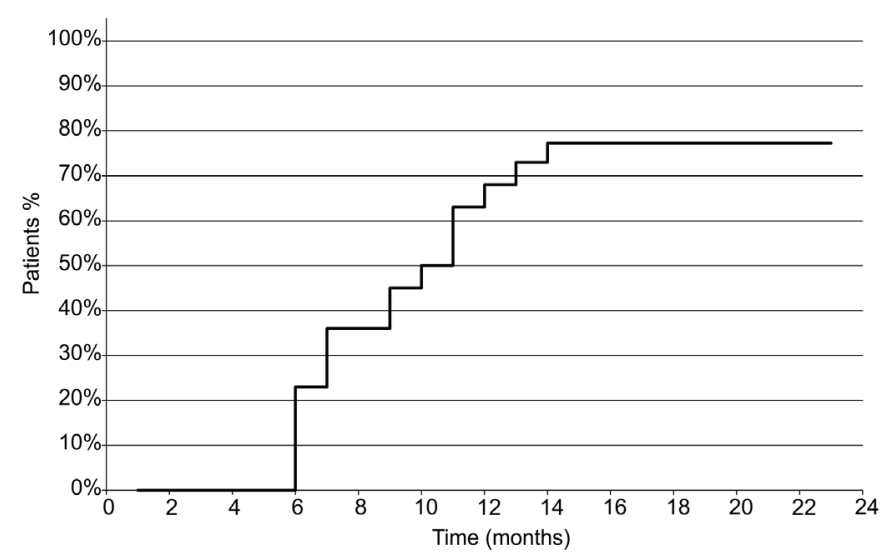

FIGURE 3 - Time required for patients to achieve CR. Patient monitoring was performed for 2 years.

2- Regarding evaluation of reticulin degree of the first BMB, $59.09 \%$ of the samples showed significant fibrosis and were graded between $2+$ and $3+$ while $13.64 \%$ revealed myelofibrosis (degree +4 ). Only $9.09 \%$ of samples collected before treatment with IM were normal (degree 0 ) and $22.73 \%$ were graded as $1+$. After treatment, less than half the samples were graded between $2+$ and $3+(22.73 \%)$, while no reticulin fibers (degree 0$)$ were visualized in $45.46 \%$ of the BMB, and only $4.54 \%$ were graded as 4+ (Figure 4).

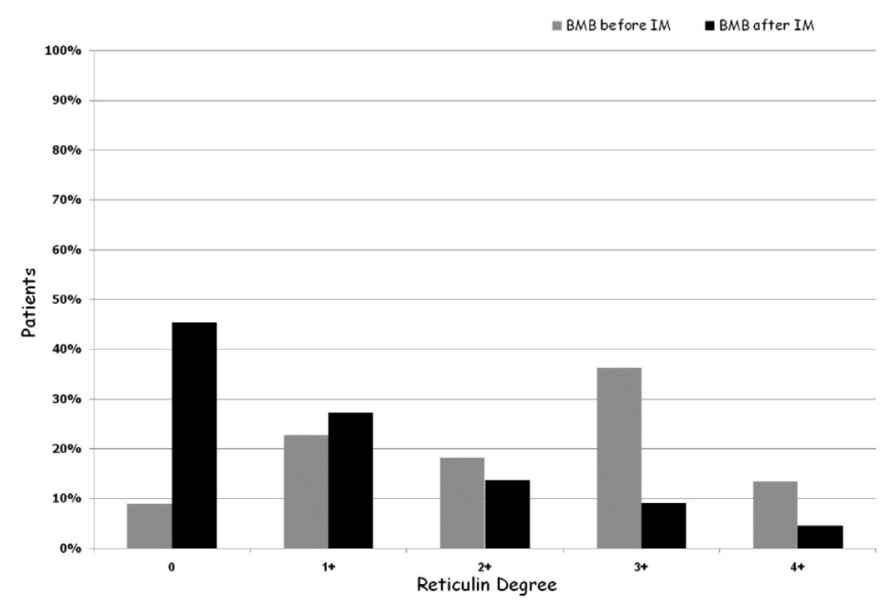

FIGURE 4 - BMB distribution of CML patients included in the study, according to Fibrosis/Reticulin degree (Gomori stain).

3-For the degree of vascularization of the first BMB, $77.27 \%$ revealed a significant increase in the number of vessels, and were graded between III and IV. Only 9.09\% of the pre-treatment samples were considered as having normal vascularity (degree I) and a small number of samples $(13.64 \%)$ were graded as II.

After IM treatment, the number of samples with a degree of vascularization between III and IV was about 4 times lower compared to the number obtained before treatment (18.18\%) and $27.27 \%$ of samples were graded at II. Most samples (54.54\%) were considered to have normal vascularity and were graded as I (Figure 5).

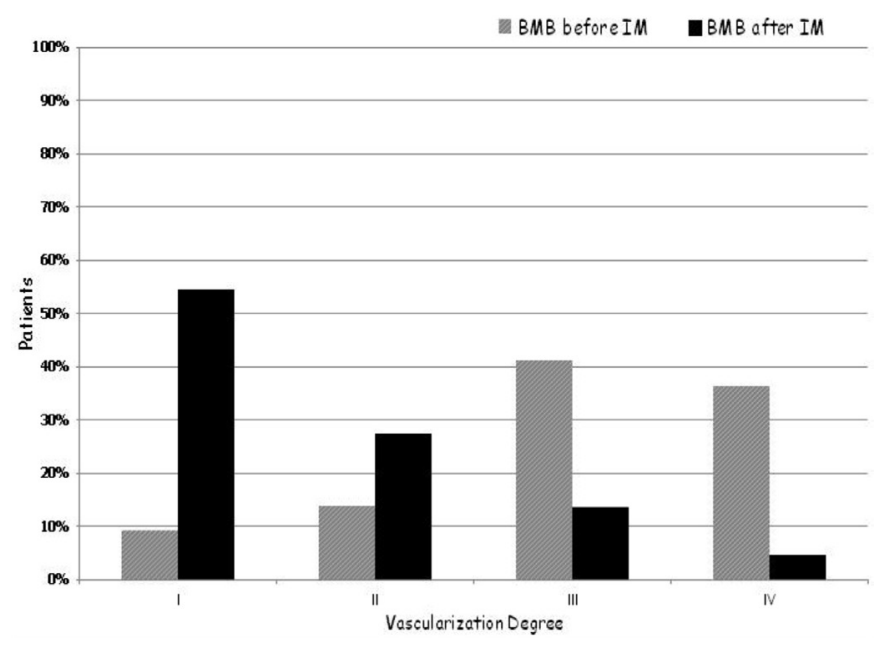

FIGURE 5 - BMB distribution of CML patients included in the study, according to vascularization degree.

4- The evaluation of reticulin degree of the BMB collected after IM was correlated to CR (Table V). Among patients who had their BMB graded at 0 reticulin, $90 \%$ achieved CR. The patients who presented $1+, 2+$ and $3+$ reticulin in the second sample, $80 \%, 75 \%$ and $50 \%$ of these achieved CR, respectively. None of the patients with second BMB graded as $4+$ reticulin achieved CR. These data are presented in Figure 6 . The results of cytogenetic tests were assessed from each patient record, observing the percentage of chromosome $\mathrm{Ph}^{1}$ positive cells and the reticulin degree of the second BMB. Points below the line represent patients who achieved $\mathrm{CR}$ and points above the line represent patients who did not achieve CR. The value of " $r$ " obtained by Spearman's correlation test was 0.8082 and the value of $P$ was $<0.0001$.

5- The results obtained from the assessment of degree of vascularization of BMB collected after IM were correlated with CR (Table VI). No patients with BMB graded as IV achieved CR. Among patients with degrees I, II and III of vascularization, $91.67 \%, 83.33 \%$ and $33.33 \%$ achieved CR, respectively. These results show that the percentage of patients responding increases as the degree of vascularization decreases. In this situation, there is also an inverse correlation with CR. These data are also shown in graph form (Figure 7). For the construction of this graph, the results of cytogenetic tests from each patient were used, 
TABLE V - Relationship between Reticulin degree of BMB from CML patients collected after IM treatment and CR

\begin{tabular}{ccc}
\hline $\begin{array}{c}\text { Reticulin degree of BMB (after } \mathbf{6} \text { to 12 } \\
\text { months of IM treatment) }\end{array}$ & $\begin{array}{c}\text { Distribution of BMB after IM by } \\
\text { reticulin degree (\%) }\end{array}$ & $\begin{array}{c}\text { \% of patients that achieved CR } \\
+1\end{array}$ \\
\hline 0 & 45.46 & 90 \\
+2 & 27.27 & 80 \\
+3 & 13.64 & 75 \\
+4 & 9.09 & 50 \\
\hline
\end{tabular}

TABLE VI - Relationship between Vascularization degree of BMB from CML patients collected after IM treatment and CR

\begin{tabular}{ccc}
\hline $\begin{array}{c}\text { Vascularization degree of BMB (after 6 } \\
\text { to 12 months of IM treatment) }\end{array}$ & $\begin{array}{c}\text { Distribution of BMB after IM by } \\
\text { vascularization degree (\%) }\end{array}$ & $\begin{array}{c}\text { \% of patients that achieved CR } \\
\text { I }\end{array}$ \\
\hline II & 54.54 & 91.67 \\
III & 27.27 & 83.33 \\
IV & 13.64 & 33.33 \\
\hline
\end{tabular}

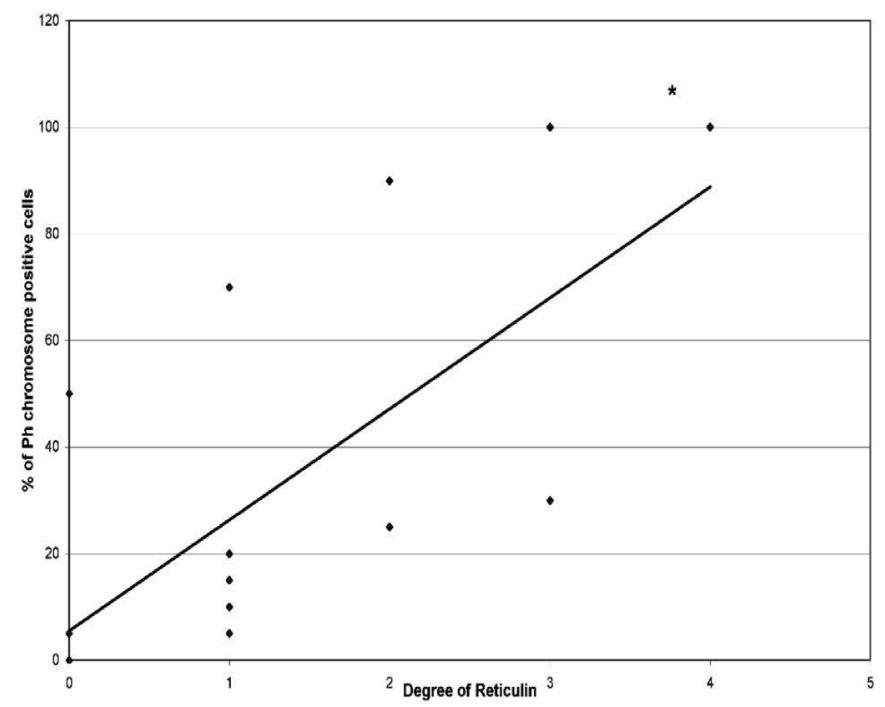

FIGURE 6 - Distribution of patients according to reticulin degree on second $\mathrm{BMB}$ and percentage of $\mathrm{Ph}^{1}$ chromosome positive cells obtained in first cytogenetic examination performed after treatment with IM. Points below the line represent patients who achieved CR, while points above the line represent non- responders. This graph was constructed assuming a cytogenetic response occurs when there is less than $35 \%$ $\mathrm{Ph}^{1}$ chromosome positive cells on the cytogenetic test (Major Cytogenetic Response).

noting the percentage of chromosome $\mathrm{Ph}^{1}$ positive cells and vascularization degree of BMB collected after treatment. Points below the line represent patients who achieved CR and points above the line represent patients who did not achieve CR. The value of " $r$ " obtained by Spearman's correlation test was 0.8179 and the value of $P$ was $<0.0001$.

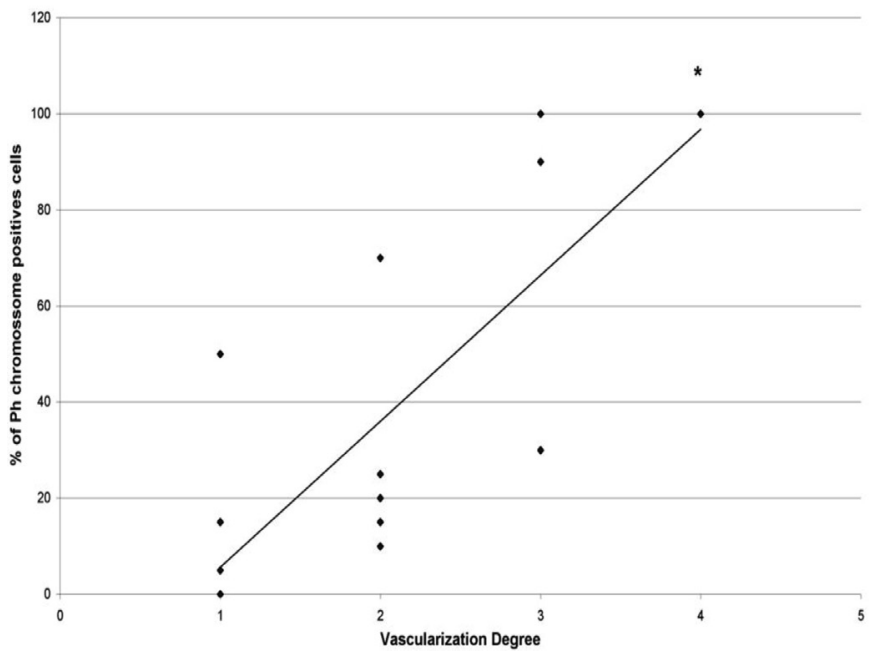

FIGURE 7 - Distribution of CML patients according to vascularization degree on second $\mathrm{BMB}$ and percentage of $\mathrm{Ph}^{1}$ chromosome positive cells obtained in first cytogenetic examination performed after treatment with IM. Points below the line represent patients who achieved $\mathrm{CR}$, while points above the line represent non-responders. This graph was constructed assuming a satisfactory response occurs when there is less than $35 \% \mathrm{Ph}^{1}$ chromosome positive cells on the cytogenetic test.

\section{DISCUSSION}

The therapy used to treat CML patients was extremely limited up until the late 1970s. This changed when IFN- $\alpha$ came into use. The disadvantage of the use of IFN- $\alpha$ is that the reversal of myelofibrosis occurs only at high doses of the drug and the side effects of this medication are significant. Attaining CR is the main goal of treatment, since this is 
directly related to patient survival. In addition, individuals who do not respond are called refractory and this event is associated to disease progression and worse prognosis (Guimarães et al., 2006; Buesche et al., 2004; Sattler, Griffin, 2003; Goldman, Mello, 2003; Druker, Talpaz, Resta, 2002).

The results obtained showed that $77.27 \%$ of patients presented less than $35 \%$ of chromosome $\mathrm{Ph}^{1}$ positive cells in the cytogenetic tests during the monitoring period. The average time to achieve CR response was ten months. Although some patients proved to be refractory to IM, they continued the treatment for at least two years. The percentage of patients that achieved CR in this study exceeded the figure reported by another study in patients resistant to IFN- $\alpha$, posteriorly treated with IM (Guilhot, 2004). The cited study, which has been used as a comparison, considered the stage of disease, and $60 \%$ of patients who were at a chronic phase achieved CR. In contrast, the $\mathrm{CR}$ attainment rates among patients who were at an accelerated phase and blast crisis were only $24 \%$ and $16 \%$, respectively. The results of this study and those of other researchers have shown that patients who failed to attain $\mathrm{CR}$ within 2 years of treatment are probably refractory and present poor prognosis (Guilhot, 2004).

The evaluation of fibrosis by reticulin analysis was investigated because the BMB of CML patients generally exhibit a significant increase in reticulin fibers (Zago, Falcão, Pasquini, 2001). Moreover, myelofibrosis is associated historically with poor CML prognosis. The plateletderived growth factor (PDGF) is a cytokine involved in myelofibrosis development in CML patients treated with IM (Kantarjian et al., 2005). Expression of this growth factor stimulates fibroblast activities including proliferation, migration and deposition of various extracellular matrix proteins, such as collagens, fibronectin, laminin and others (Anjos, Alvarez-Silva, Borelli, 2004). Some studies have shown that IM also acts on the BM stroma (Bueso-Ramos et al., 2004; Klion, 2004). The drug acts not only by blocking the ATP link to the binding site of protein tyrosine kinase BCR-ABL but also acts by blocking the bind site of PDGF, present in fibroblasts. These cells are involved in the release of various elements that compose the extracellular matrix of BM, such as reticulin. IM has an independent anti-fibrotic effect on BM of CML patients, while IFN- $\alpha$ proves ineffective in patients with myelofibrosis at diagnosis (Kantarjianet al., 2005; Buescheet al., 2004; ; Mello, 2004;; Klion et al., 2004; Suetterlin et al., 2004; Hasselbach et al., 2003).

Regarding the reticulin analysis of $\mathrm{BMB}, 18.18 \%$ of samples collected before IM treatment presented a thin fiber network in most fragments (degree $2+$ ), 36.36\% showed a diffuse network of thin fibers with scattered thick fibers (degree $3+$ ) and $13.64 \%$ of samples showed coarse fibers and bundles of collagen (degree $4+$ ), giving a total of $68.18 \%$ with significant changes in the reticulinic network. In contrast, $45.46 \%$ of BMB collected after the therapy revealed absence of reticulin (degree 0 ) and $27.27 \%$ showed thin and scattered fibers or a focal network (degree $1+), 13.64 \%$ of samples were graded as $2+$ and $9.09 \%$ as $3+$. Interestingly, no samples revealed the highest degree of reticulin $(4+)$. These results strengthen the hypothesis that the drug acts on the BM stroma and has the ability to reverse fibrosis. Several reports have shown significant reductions in myelofibrosis in patients with CML receiving IM. Bueso-Ramos et al. (2004) reported resolution of at least 2 degrees in 19 of their 31 patients $(61 \%)$ and by at least 1 degree in 34 patients (85\%). However, no correlation with cytogenetic response was found. Buesche et al (2007) also showed resolution of fibrosis, although during a follow-up period of up to 4.8 years, small foci with abnormal fiber increase emerged. In our study, patients were followed for only two years. In addition, IM is also being tested as a potent antifibrotic therapeutic agent in several diseases and beneficial results have been found that may not only halt further progression but also induce regression of preexisting dermal fibrosis (Akhmetshina et al., 2009).

As in CML, there is a change in the distribution of elements present in the extracellular matrix of $\mathrm{BM}$, and it has been suggested that the leukemic cells are protected or "hidden" by these elements. The increased fibrosis could hinder the performance of the drug, not allowing the apoptosis of $\mathrm{Ph}^{1}$ chromosome positive cells (Klion et al., 2004). The study suggested that in samples where there was a reduction of fibrosis, the drug worked more easily on the leukemic cells.

As the IM acts on the stroma of BM, there is the possibility that the reduction of fibrosis provides better conditions for the performance of the drug, which explains the analysis of correlation between CR and reticulin degree. The present results showed that there is a significant correlation between $\mathrm{CR}$ and degree of reticulin. Among the patients with degree 0 of reticulin on the second BMB, $90 \%$ had achieved CR. Of those who had degree $1+$ and $2+$ of reticulin, $80 \%$ and $75 \%$ achieved CR, respectively. Finally, a total of $50 \%$ and $0 \%$ of patients who had their samples graded as $3+$ and $4+$ responded, respectively. However, Kantarjian et al. (2005), in a study of 110 patients with CML who had severe fibrosis $(61 \%)$ and mild-moderate fibrosis, found no association between severe marrow fibrosis and poor response to IM or worse prognosis. These results do not corroborate with findings of our study. This is probably because the patients were older (range 24-81 years) and the association was performed with the first biopsy, since the prevalence of 
myelofibrosis increases with age. In addition, our analysis included only 22 patients.

An increase in angiogenesis has been observed in patients with hematological diseases, including CML (Lundberget al. 2000). One study investigated the role of IM on the BM angiogenesis in comparison with Hydroxyurea and IFN- $\alpha$. The paper reported that, in vitro, the expression of Vascular Endothelial Growth Factor (VEGF) reduced after treatment with IM. Also, the study suggested that the decrease in microvascularization presents an association with the reversal of myelofibrosis (Kvasnicka et al., 2004). The methods used in the present study to assess the vascularity of BM followed were the same as those adopted in the aforementioned study, which employed the technique of immunohistochemical expression of CD34 present in endothelial cells. Akin to fibrosis, vascularization is also altered in CML. Therefore, it has been suggested that the number of vessels also have an important role in disease progression and therapeutic response (Kvasnickaet al., 2004). And as a consequence, there may be a correlation with the prognosis of patients. Bone marrow study of angiogenesis was performed by using microvessel visual grading with antibody CD 34 . The analysis showed that, of the first samples collected prior to treatment with IM, degree IV occurred in $36.36 \%$ patients, degree III in $40.91 \%$, degree II in $13.64 \%$, and degree I in only $9.09 \%$. However, in the analysis of vessels on the second biopsy after IM treatment, few patients showed degree III, degree II was evident in $27.27 \%$ and more than half the samples (54.54\%) presented degree I. The results of our study corroborate those reported in the literature, showing that blood vessel density of patients decreased after 3 months on IM (Rumpel, Friedrich, Deininger, 2003).

Since some researchers have shown that IM acts on BM vascularization, we also performed correlation analysis of this parameter with CR. Our results showed a high correlation between the vascularization of BM samples collected after treatment and CR. Among the patients with degree I and II of vascularization on the second $\mathrm{BMB}, 91.67 \%$ and $83.33 \%$ attained $\mathrm{CR}$, respectively. Among patients whose samples were graded as III, 33.33\% responded, while none of the patients with degree IV of vascularization achieved $C R$.

The present study strengthens the hypothesis that the stroma of patients with CML presents significant changes, and that IM is effective in normalizing this microenvironment, demonstrating correlation between stabilization and CR. In addition, in samples where the stroma is more disorganized, the drug appears to have greater difficulty acting. Consequently, the BM status of patients with CML has a direct correlation with prognosis.

\section{REFERENCES}

ALVES, A.C. Histologia de medula óssea. Rev. Bras. Hematol. Hemoter, v.31, n.3, p.183-188, 2009.

AKHMETSHINA, A.; VENALIS, P.; DEES, C.; BUSCH, N.; ZWERINA, J.; SCHETT, G. Treatment with imatinib prevents fibrosis in different preclinical models of systemic sclerosis and induces regression of established fibrosis. Arthritis Rheum., v.60, n.1, p219-224, 2009.

ANJOS, A.R.; ALVAREZ-SILVA, M.; BORELLI, P. Interaction of leukemic cells with proteins of the extracellular matrix. Rev. Bras. Hematol. Hemoter., v.26, n.3, p.206-211, 2004.

BRASIL. Ministério da Saúde. Secretaria de Assistência à Saúde. Protocolo de Diretrizes Terapêuticas - Leucemia Mielóide Crônica do Adulto, 2001. Rio de Janeiro. p.1-4.

BUESCHE, G.; FREUND, M.; HEHLMANN, R.; GEORGII, A.; GANSER, A.; HECKER, H.; HEIMPEL, H.; FONATSCH, C.; HEINZE, B.; PFIRRMANN, M.; HOLGADO, S.; SCHMEIL, A.; TOBLER, A.; HASFORD, J.; BUHR, T.; KREIPE, H. H. Treatment intensity significantly influencing fibrosis in bone marrow independently of the cytogenetic response: meta-analysis of the long-term results from two prospective controlled trials on chronic myeloid leukemia. Leukemia, v.18, n.9, p.1460-1467, 2004.

BUESO-RAMOS, C.E.; CORTES, J.; TALPAZ, M.; O’BRIEN, S.; GILES, F.; RIOS, M.B.; MEDEIROS, L.J.; KANTARJIAN, H. Imatinib mesylate reduces bone marrow fibrosis in patients with chronic myelogenous leukemia. Cancer, v.101, n.2, p.332-336, 2004.

DABBS, D. Diagnostic immunohistochemistry. 2.ed. Pittsburgh: Elsevier, 2006. p. 1-37.

DRUKER, B.J.; TALPAZ, M.; RESTA, D.J. Efficacy and safety of a specific inhibitor of the BCR-ABL tyrosine kinase in chronic myeloid leukemia. N. Engl. J. Med., v.344, n.14, p.1031-1037, 2002.

FADERL, S.; TALPAZ, M.; ESTROV, Z.; O'BRIEN, S.; KURZROCK, R.; KANTARJIAN, H.M. The biology of chronic myeloid leukemia. N. Engl. J. Med, v.341, n.3, p.164-172, 1999.

GEARY, C.G. The story of chronic myeloid leukemia. British J. Haematol., v.110, n.1, p.2-11, 2000. 
GOLDMAN, J.M.; MELLO, J.V. Chronic myeloid leukemiaadvances in biology and new approaches to treatment. $N$. Engl. J. Med., v.349, n.15, p.1451-1464, 2003.

GUILHOT, F. Sustained durability of responses plus high rates of cytogenetic responses result in long-term benefit for newly diagnosed chronic-phase chronic myeloid leukemia (CML-CP) treated with imatinib (IM) therapy: update from the IRIS Study (abstract). Blood, v.104, n.1, p.10, 2004.

GUIMARÃES, J.R. Q. Manual de oncologia. 2.ed.São Paulo: BBS Editora, 2006. p.219-235.

HASSELBACH, H.C.; BJERRUM, O.W.; JENSEN, B.A.; CLAUSEN, N.T.; HANSEN, P.B.; BIRGENS, H.; THERKILDSEN, M.H.; RALFKJAER, E. Imatinib mesylate in idiopathic and postpolycythemic myelofibrosis. Am. J. Hematol., v.74, n.4, p.238-242, 2003.

KANTARJIAN, H.M.; BUESO-RAMOS, C.E.; TALPAZ, M.; O'BRIEN, S.; GILES, F.; FARDEL, S.; WIERDA, W.; RIOS, M.B.; SHAN, J.; CORTES, J. Significance of myelofibrosis in early chronic-phase myelogenous on imatinib mesylate therapy. Cancer, v.104, n.4, p.777-780, 2005.

KLION, A. D.; ROBYN, J.; AKIN, C.; NOEL, P.; BROWN, M.; LAW, M.; METCALFE, D.D.; DUNBAR, C.; NUTMAN, T.B. Molecular remission and reversal of myelofibrosis in response to imatinib mesylate treatment in patients with the myeloproliferative variant of hypereosinophilic syndrome. Blood, v.103, n.2, p.473-478, 2004.

KVASNICKA, H. M.; THIELE, J.; STAIB, P.; SCHMITTGRAEFF, A.; GRIESSHAMMER, M.; KLOSE, J.; ENGELS, K.; KRIENER, S. Reversal of bone marrow angiogenesis in chronic myeloid following imatinib mesylate (STI571) therapy. Blood, v.103, n.9, p.3549-3551, 2004.

LICHTMAN, M.A.; BEUTLER, E.; KIPPS, T.J.; SELIGSOHN, U.; KAUSHANSKY, K.; PRCHAL, J.T. Williams Hematology. 7.ed. New York: McGraw-Hill Companies, 2006. p.1245-1263.

LUNDBERG, L.G.; LERNER, R.; SUNDELIN, P.; ROGERS, R.; FOLKMAN, J.; PALMBLAD, J. Bone marrow in polycytemia vera, chronic myelocytic leukemia, and myelofibrosis has an increased vascularity. Am. J. Pathol., v.15, n.7, p.15-19, 2000

MELLO, M. C.R. Avaliação da resposta clínica e citogenética em portadores de leucemia mielóide crônica, tratados com inibidor da tirosina quinase (imatinibe). São Paulo, 2004. p.1-12 [Graduated Thesis. Faculty of Medicine. University of São Paulo].
MICHALANY, J. Técnica histológica em anatomia patológica: com instruções para o cirurgião, enfermeira e citotécnico. São Paulo: EPU, 1980. p.52-109.

PANTELI, K.; ZAGORIANAKOU, N.; BAI, M.; KATSARAKI, A.; AGNANTIS, N.J.; BOURANTAS, K. Angiogenesis in chronic myeloproliferative diseases detected by CD34 expression. Eur. J. Haematol., v.72, n.6, p.410-415, 2004.

RUMPEL, M.; FRIEDRICH, T.; DEININGER, M.W.N. Imatinib normalizes boné marrow vascularity in patients with chronic myeloid leukemia in first chronic phase. Blood, v.101, n.11, p.4641-4643, 2003.

SATTLER, M.; GRIFFIN, J.D. Molecular mechanisms of transformation by the BCR-ABL oncogene. Semin. Hematol., v.40, n.2, p.4-10, 2003.

SAVAGE, D.G, ANTMAN, K.H. Imatinib- a new oral target therapy. N. Engl. J. Med., v.346, n.9, p.683-693, 2002.

SAWYERS, C.L. Chronic myeloid leukemia. N. Engl. J. Med., v.340, n.17, p.1330-1338, 1999.

SUETTERLIN, R.; BASCHONG, W.; LAENG, R.; HUBERT, L.R. Immunofluorescence and confocal laser scanning microscopy of chronic myeloproliferative disorders on archival formaldehyde-fixed bone marrow. J. Histochem. Cytochem., v.52, n.3, p.347-354, 2004.

VITURI, C. L.; ALVAREZ-SILVA, M.; TRENTIN, A. G.; BORELLI, P. Alterations in proteins of bone marrow extracellular matrix in undernourished mice. Braz. J. Med. Biol. Res., v.33, n.8, p.889-895, 2000.

VITURI, C.L.; ALVAREZ-SILVA, M.; TRENTIN, A.G.; BORELLI, P. Capacidade da matriz extracelular da medula óssea de induzir proliferação de células mielóides in vitro no modelo de desnutrição protéica em camundongos. Rev. Bras.Cienc. Farm., v.44, n.3, p.494-501, 2006.

ZAGO, M.A.; FALCÃO, R.P.; PASQUINI, R. Hematologia fundamentos e práticas. São Paulo: Editora Atheneu, 2001. $1081 \mathrm{p}$.

Received for publication on $25^{\text {th }}$ May 2010. Accepted for publication on $22^{\text {nd }}$ October 2010. 